\title{
ЗАГАСАННЯ ОПТИЧНОГО СИГНАЛУ У ВОЛЗ
}

\section{Вступ}

Технічні характеристики і параметри сучасних волоконно-оптичних ліній зв'язку (ВОЛЗ) такі як висока інформаційна ємність та швидкість передачі; велика довжина пасивних ділянок і ділянок без використання регенераторів; висока завадостійкість; економічна ефективність та інші сприяють активному використанню ВОЛЗ при побудові i модернізації різноманітних ліній зв'язку. Також вважається, що ВОЛЗ мають високу скритність і захищеність.

3 точки зору несанкціонованого отримання інформації, яка передається лініями зв'язку, найдоступнішими є канали зв'язку. Запобігання витоку інформації з мереж зв'язку, в наш час, є достатньо важким завданням. Принцип роботи і побудова більшості з елементів ВОЛЗ $\epsilon$ відомими і описаними в літературі. Але, у відкритій літературі майже немає інформації щодо методів і можливостей несанкціонованого підключення до ВОЛЗ.

Детальний аналіз захищеності інформації, що передається в ВОЛЗ, розпочався відносно недавно, і на цей час цю проблему досліджено недостатньо. Аналіз захисту інформації в ВОЛЗ найкраще починати з побудови моделі втрат або загасання. Це обумовлено точками витоку інформації в лінії зв'язку.

\section{Основна частина}

Виходячи з особливостей оптичного волокна модель загасання сигналу має містити дві складові:

- загасання оптичного сигналу (ОС), обумовлене фізичними особливостями оптичного волокна (ОВ);

- загасання ОС, обумовлене навмисними діями на ОВ потенційного порушника.

Загасання ОС за рахунок фізичних особливостей ОВ обумовлюється існуванням втрат при передачі інформації.

При розповсюдженні оптичного імпульсу уздовж однорідного волокна потужність $\mathrm{P}$ i енергія W імпульсу зменшуються через втрати енергії, викликані розсіюванням i поглинанням за експоненціальним законом (закон Бугера, рис. 1) і визначається, як:

$$
P(L)=P(\mathbf{0}) \exp (-\propto L), W(L)=W(\mathbf{0}) \exp (-\propto L)
$$

де $P(L)$ - потужність випромінювання на відстані L;

$P(0)$ - потужність випромінювання в початковій точці;

$\propto$ - коефіцієнт затухання, якій визначається виразом:

$$
\propto=\left(\frac{\mathbf{1}}{L}\right) \ln \left[\frac{p(0)}{P(L)}\right]
$$

В одиницях дБ/км коефіцієнт ослаблення $\propto$ може бути виражений, як:

$$
\propto\left(\frac{d B}{K M}\right)=\frac{10}{L} \log \left[\frac{P(0)}{P(L)}\right]=4.343 \propto\left(\mathrm{KM}^{-1}\right)
$$




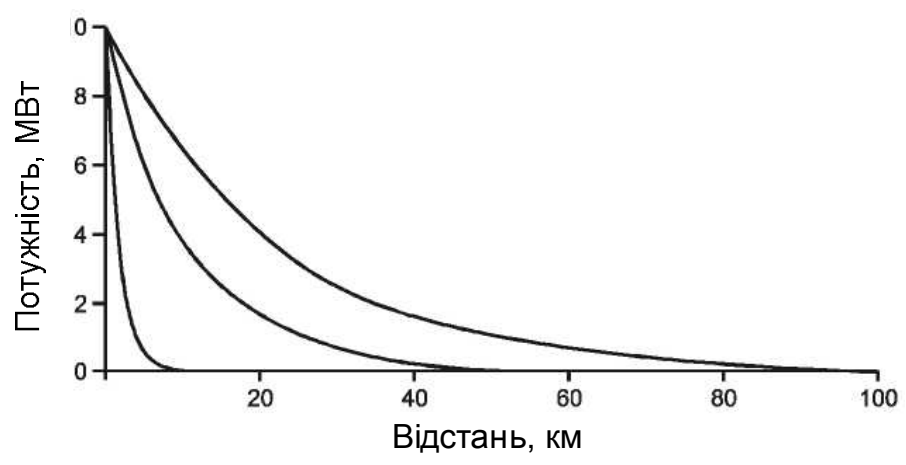

Рис 1.Закон Бугера. Залежність потужностей світлових імпульсів від відстані вздовж волокна на довжинах хвиль 1550 нм, 1300 нм і 985 нм.

Коефіцієнт загасання є функцією від довжини хвилі. На рис.2 подано графік залежності коефіцієнта загасання від довжини хвилі.

Загасання світла в ОВ складається 3 втрат на поглинання, втрат на розсіювання i кабельні втрати. В свою чергу втрати на поглинання $\left(\alpha_{\text {погл }}\right)$ i на розсіювання $\left(\alpha_{\text {роз }}\right)$ разом

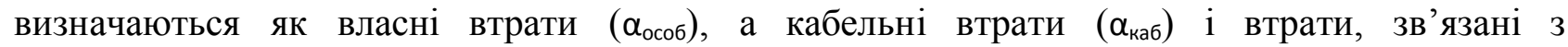
несанкціонованим доступом (НСД) через їх фізичну природу можна назвати додатковим втратами $\left(\alpha_{\text {дод }}\right)$.

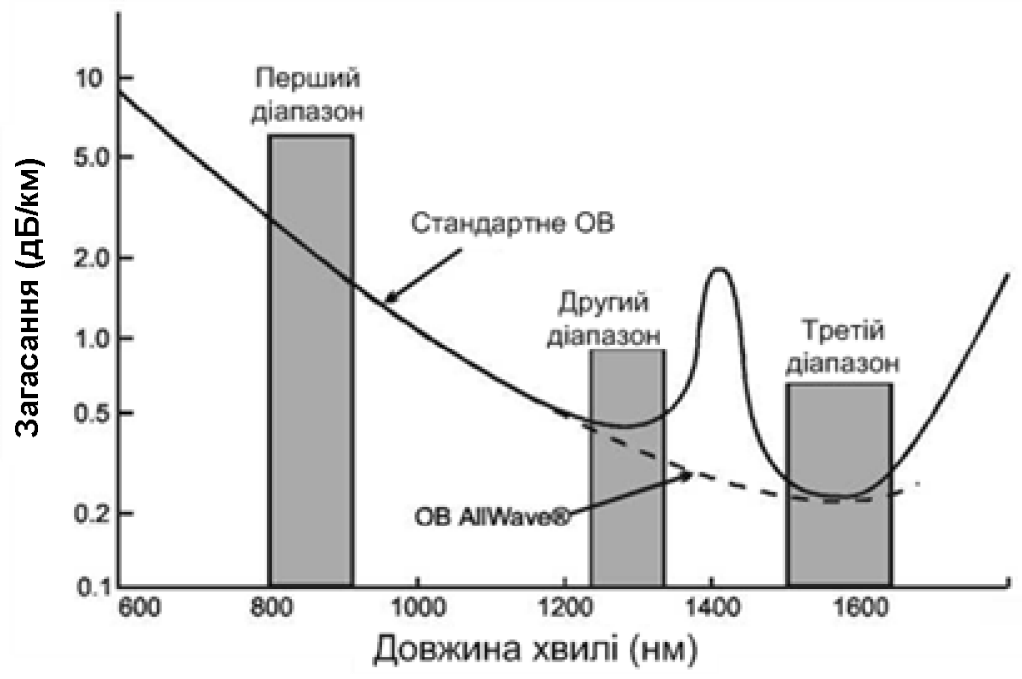

Рис 2.Залежність коефіцієнта загасання від довжини хвилі

Загасання сигналу в ОВ залежить від довжини хвилі і становить 0,5 дБ/км для 1300 нм і 0,3 дБ/км для 1550 нм стандартного одномодового волокна (суцільна лінія). Це волокно має пік загасання в області 1400 нм, який є результатом поглинання енергії молекулами води. Пунктирною лінією на рис. 2 показано загасання для волокна Allwave $®$, вільного від води.

Таким чином, повне загасання в ОВ з урахуванням НСД можна представити в такому вигляді:

$$
\alpha=\alpha_{\text {особ }}+\alpha_{\text {дод }}=\alpha_{\text {погл }}+\alpha_{\text {роз }}+\alpha_{\text {каб }}+\alpha_{\text {нсд }}
$$

Втрати на поглинання $\left(\alpha_{\text {погл }}\right)$ складаються з втрат в кварцовому склі, які визначаються, як ультрафіолетове і інфрачервоне поглинання, а також з втрат, пов'язаних 3 поглинанням оптичної енергії на домішках (Втрати в кварцовому склі викликаються власним поглинанням атомами оптичного матеріалу - кварцу ( і поглинанням атомними дефектами в скляному

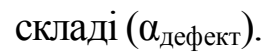

$$
\alpha_{\text {погл }}=\alpha_{\text {с.о.м. }}+\alpha_{\text {доміш }}+\alpha_{\text {дефек }}
$$

Основною реакцією скловолокна на атомне випромінювання є збільшення загасання оптичної енергії унаслідок створення атомних дефектів, або центрів ослаблення, які 
поглинають оптичну енергію.

Поглинання на домішках (забрудненнях) виникає переважно від іонів металу і від ОН (водяних) іонів. Домішки металу обумовлюють втрати від 1 до 10 дБ/км.

Раніше ОВ мали високий рівень вмісту ОН-іонів, який призводив до великих піків поглинання на довжинах хвиль 1400, 950 і 725 нм. Шляхом зменшення залишкового вмісту ОН-іонів у волокні (для одномодових волокон - близько 1 частки на мільярд), на цей час ОВ мають номінальні загасання 0,5 дБ/км на 1300 нм і 0,3 дБ/км на 1550 нм, як показано суцільною лінією на рис. 2. Слід звернути увагу на центр домішки в районі 1480 нм, який $\epsilon$ домішкою $\mathrm{OH}$-іонів у волокні. На цій довжині хвилі завжди наявний пік поглинання в кварцовому волокні.

Так звані центри домішок, залежно від типу домішки, поглинають світлову енергію на певних, властивих даній домішці, довжинах хвиль і розсіюють іï у вигляді теплової енергії.

Власне поглинання атомами оптичного матеріалу складається 3 :

- поглинання електронів в ультрафіолетовій області;

- поглинання електронів на межі інфрачервоної області.

Ультрафіолетова межа поглинаючих смуг електронів відповідно до закону Урбача визначається як:

де $\mathrm{C}$ i $\mathrm{E}_{0}$ емпіричні сталі і $\mathrm{E}$-енергія фотону.

$$
\alpha_{\text {погл }}=\mathrm{C} \exp \left(\mathrm{E} / \mathrm{E}_{0}\right)
$$

Характерний розподіл ультрафіолетового поглинання представлений на рис. 3

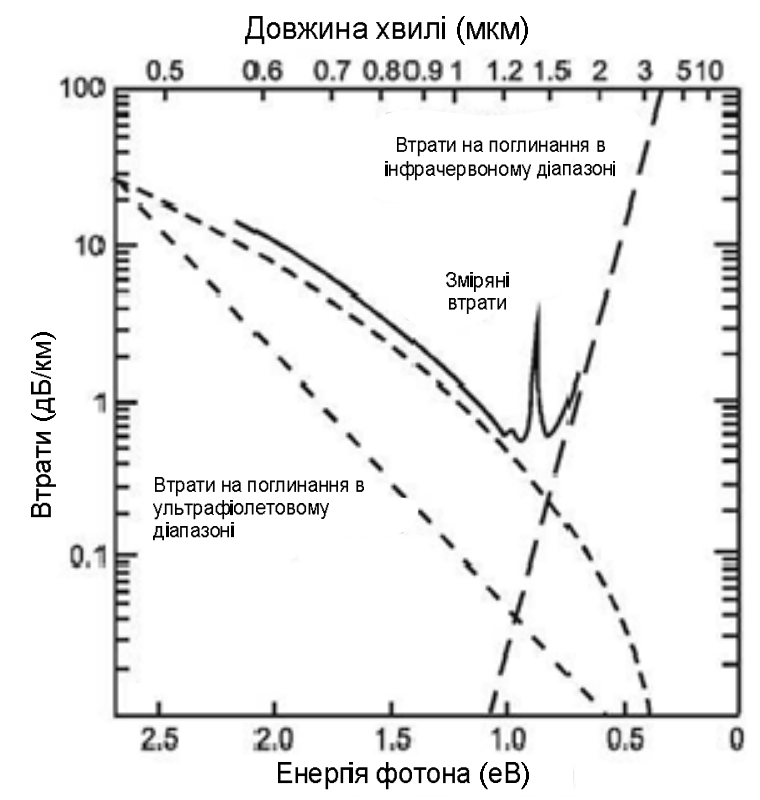

Рис 3.Розподіл ультрафіолетового і інфрачервоного поглинання 


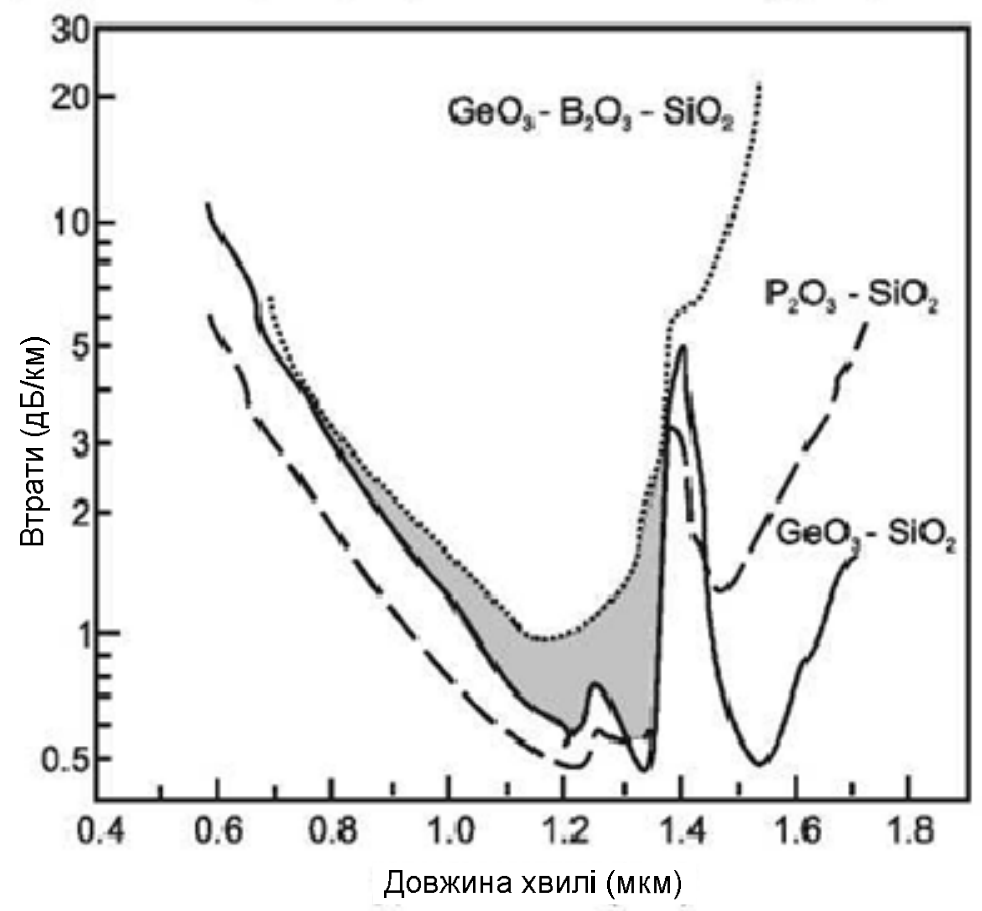

Рис.4. Порівняння інфрачервоного поглинання, викликаного різними домішками.

Значення загасання в ультрафіолетовій області є малим, в порівнянні із загасанням в інфрачервоній області для малих значень енергії фотона. Власні втрати на поглинання зростають при збільшенні довжини хвилі випромінювання і стають значними в ультрафіолетовій і інфрачервоній областях. Так при довжині хвилі випромінювання більшій 1,6 мкм звичайне кварцове скло втрачає властивість прозорості через зростання втрат, які пов'язані з інфрачервоним поглинанням (рис.3).

На рис. 4 представлено залежності втрат від довжини хвилі випромінювання для ОВ 3 кварцового скла 3 гранично малими втратами і багатокомпонентними ОВ, виготовлених 3 різних оптичних матеріалів.

Розсіюванням представляє процес видалення частини енергії 3 хвилі, що розповсюджується, з наступною емісією деякої частини цієї енергії.

Джерела виникнення розсіювання в OB:

- маленькі газові бульбашки;

- неоднорідний склад оптичного матеріалу;

- вигин ОВ.

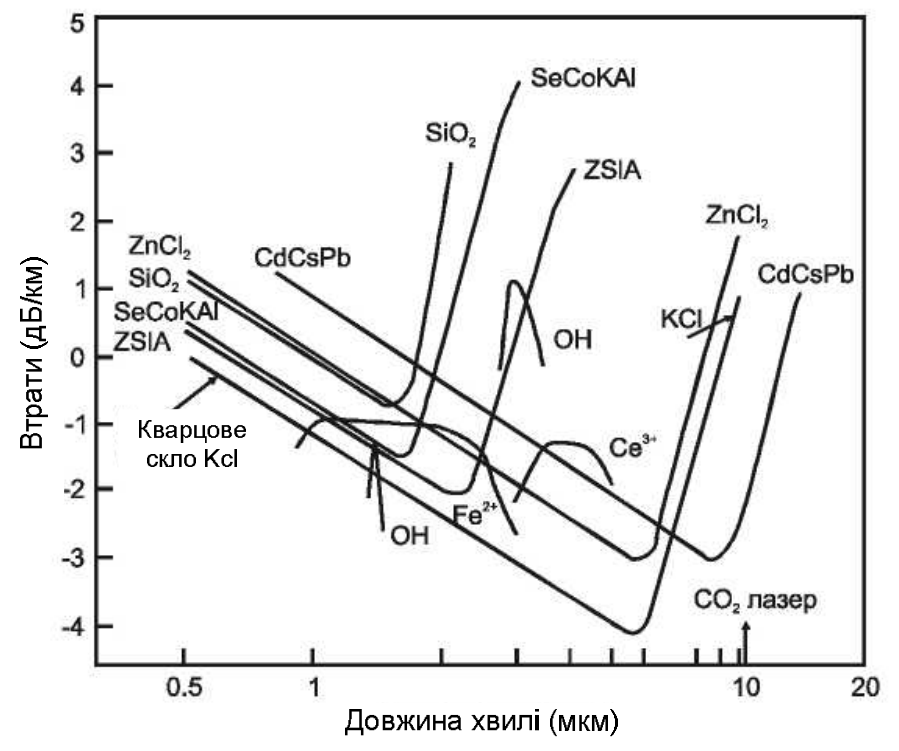


Втрати на розсіювання стають визначальним чинником загасання у волокні вже 3 1970 р., коли була досягнута чистота ОВ порядка 99,9999\%.

Подальшому зменшенню загасання перешкоджали втрати на розсіювання. У загальному виді втрати на розсіювання визначаються наступним виразом:

$$
\alpha_{\text {роз }}=\alpha_{\text {рел }}+\alpha_{\text {ми }}+\alpha_{\text {इзгиб }}+\alpha_{\Sigma \text { стик }}+\alpha_{\text {вкр }}+\alpha_{\text {врбм }}
$$

де $\alpha_{\text {рел }}$ - втрати, обумовлені Релєєвським розсіюванням. Причиною Релєєвського розсіювання $\epsilon$ те, що атоми в склі (Sio2) мають випадковий просторовий розподіл, і локальні зміни в складі приводять до локальної зміни індексу заломлення, що і викликає розсіювання оптичної енергії. Тому хвилі малої довжини повинні більше розсіватися i, отже, мати вищі втрати, ніж хвилі з більшою довжиною.

$\alpha_{\text {ми }}$ - втрати, обумовлені Мі-розсіюванням. Даний тип лінійного розсіювання виникає на іонах домішки, розмір яких порівнюється з довжиною хвилі. У високоякісних ОВ такі втрати відсутні.

$\alpha_{\text {इзгиб }}$ - сумарні втрати, обумовлені мікро $\left(\alpha_{\text {мікро }}\right)$ i макро $\left(\alpha_{\text {макро }}\right)$ вигинами ОВ, що визначаються виразом:

$$
\alpha_{\text {इзгиб }}=\alpha_{\text {мікро }}+\alpha_{\text {макро }}
$$

Мікровигини виникають в процесі виготовлення ОВ і при формуванні пластикового конверту в процесі виготовлення оптичного кабеля. Макровигини виникають в процесі прокладки оптичного кабеля i $\epsilon$ функцією від радіусу вигину ОВ. Тоді втрати на макровигинах можна представити виразом:

$$
\alpha_{\text {макро }}=2 \alpha_{\text {п.п. }}+\alpha_{\text {п.м.у. }}+\alpha_{\text {п.м. }}
$$

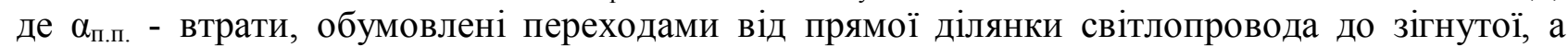

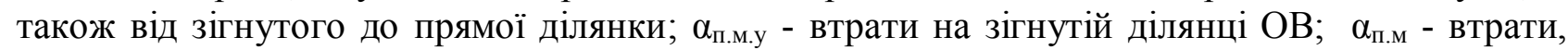
обумовлені наявністю мікротріщин; $\alpha_{\Sigma \text { стик }}$ - сумарні втрати, обумовлені стиковкою ОВ i визначувані внутрішніми $\left(\alpha_{\text {внутр }}\right)$ і зовнішніми $\left(\alpha_{\text {зовн }}\right)$ втратами згідно виразу:

$$
\alpha_{\text {Естик }}=\alpha_{\text {внутр }}+\alpha_{\text {зовн }}
$$

Внутрішні втрати визначаються важко контрольованими чинниками - парною варіацією діаметрів серцевин, показників заломлення, числових апертур, ексцентриситетів «серцевина/оболонка», концентричністю серцевини у волокнах, що сполучаються. Можна отримати випадкові зміни перерахованих чинників, оскільки вони залежать не від конструкції з'єднувача, а від технології виробництва ОВ.

Причинами зовнішніх втрат є недосконалість конструкції з'єднувача, а також процесу складання ОВ і з'єднувача. Зовнішні втрати залежать від механічного нестикування (кутовий, радіальний і осьовий зсув), шорсткості на торці серцевини, чистоти ділянки i наявності зазору між торцями з’єднуваних ОВ. Наявність зазору приводить до появи френелівського віддзеркалення через утворення середовища з показником заломлення, відмінним від показника заломлення ОВ.

$$
\alpha_{\text {зовн }}=\alpha_{\text {кут }}+\alpha_{\text {рад }}+\alpha_{\text {ось }}+\alpha_{\text {обр }}
$$

де $\alpha_{\text {кут }}$ - втрати, викликані кутовим зсувом світлопроводів; $\alpha_{\text {рад }}$ - втрати, викликані радіальним

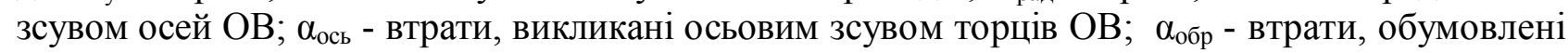
зворотним френелівським віддзеркаленням.

3 врахуванням викладеного, вираз (10) прийме наступний вигляд:

$$
\alpha_{\text {इстик }}=\alpha_{\text {внутр }}+\alpha_{\text {кут }}+\alpha_{\text {рад }}+\alpha_{\text {ось }}+\alpha_{\text {обр }} \text {. }
$$

Сумарні втрати, обумовлені стикуванням OB, також називають втратами, що вносяться.

- втрати, обумовлені вимушеним комбінаційним розсіюванням. Це розсіювання називається розсіюванням Рамана-Мандельштама і виникає у волокні тоді, коли оптична потужність, що проходить в ньому, досягає деякого порогу. Поріг розсіювання залежить від площі поперечного перетину і довжини ОВ, а також від коефіцієнта втрат. Розсіювання розповсюджується переважно у напрямі початкового випромінювання. 
- втрати, обумовлені вимушеним розсіюванням Мандельштама-Бріллюена. Фізична суть розсіювання полягає в тому, що при достатньо високому рівні потужності випромінювання відбувається зміна енергетичних квантових станів молекул і атомів ОВ, що виражається в коливальному русі молекул. Це приводить до флуктуації щільності речовини, тобто до виникнення акустичних фононів. На цих фононах відбувається нелінійне розсіювання світла, що полягає в тому, що фотони віддають частину енергії акустичним фононам, внаслідок чого в спектрі випромінювання з'являються нові компоненти, які називають стоксовими.

Для забезпечення працездатності ВОЛЗ необхідно, щоб для повного загасання $\alpha$ сигналу у волоконно-оптичному тракті виконувалися наступні умови:

$$
\begin{gathered}
\alpha=\mathrm{P}_{\text {пер }}-\mathrm{P}_{\text {пр- }}-\alpha_{\text {зап при }} \mathrm{P}_{\text {пр }} \geq \mathrm{P}_{\text {пр.мін }}, \\
\Delta \alpha \leq \alpha_{\text {зап }}
\end{gathered}
$$

де $\mathrm{P}_{\text {пер }}$ - потужність випромінювання оптичного передавача (дБ/м); $\mathrm{P}_{\text {пр }}$ - потужність на вході

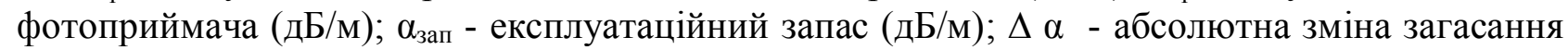
тракту при зміні температури навколишнього середовища. Параметр $\alpha$ визначає довжину регенераційної ділянки.

Таким чином, значення втрат потужності $\mathrm{P}_{l}$ в довільній точці визначається розв'язком системи рівнянь:

$$
\mathrm{P}_{l}=\left\{\begin{array}{l}
\left.\mathrm{P}_{0} \mathrm{e}^{-(} \alpha_{\text {погл }}+\alpha_{\text {релл }}+\alpha_{\text {мі }}+\alpha_{\text {इзгиб }}+\alpha_{\Sigma \text { стик }}+\alpha_{\text {вкр }}+\alpha_{\text {врби }}+\alpha_{\text {нсд }}\right) l,>0 \\
\mathrm{P}_{0}, l=0
\end{array}\right.
$$

Дії з навмисного зняття інформації з ВОЛС повинні бути направленими на отримання необхідної частки енергії основного випромінювання або максимальної частини потужності випромінювання за рахунок використання існуючих, а також створення додаткових втрат, $\mathrm{i}$ повинні складатися з наступних кроків:

1.Фіксації з подальшим посиленням і обробкою випромінювання витікаючих мод.

2.Фіксації з подальшим посиленням і обробкою випромінювання за рахунок Релєєвського розсіювання.

3.Фіксація 3 подальшим посиленням $\mathrm{i}$ обробкою випромінювання в місцях зварювання, роз'ємних з'єднань.

4.Пошук місць 3 підвищеним випромінюванням (місць 3 мікровигинами, мікротріщинами) з подальшим посиленням і обробкою прийнятого сигналу.

5.Створення додаткових вигинів, натягнень, порушень оболонки 3 метою збільшення потужності витоку основного випромінювання або витоку, обумовленого фізичними властивостями ОВ.

6.Розрив волокна i застосування спеціальних засобів i методів, направлених на мінімізацію виявлення вчиненої дії.

7.Дії, направлені на збій приймання-передавання інформації шляхом збільшення значення хроматичної дисперсії в багатомодових оптичних кабелях.

Системи, що використовують п. 5, 6 і 7 реально існують і принцип їх дії описано в існуючій літературі. Розробку засобів за п. 1-4 можна розглядати як перспективні, оскільки їх використання ніяк не позначається на сигналі, який передається по ОВ, і виявлення несанкціонованої дії зведено до мінімуму.

На підставі запропонованої вище моделі можна приступати до побудови системи захисту інформації

Відомі системи захисту мають два напрями:

1. Системи захисту, направлені на контроль ВОЛЗ;

2. Системи захисту, направлені на захист самої інформації.

Обидва ці напрями позволяють здійснювати повний контроль дій, вказаних в п 5 і 6 тегів. Для вказаних в п.1-4 тегів ці напрями (крім криптографічних) є непридатними.

Крім того для побудови складних систем захисту необхідно враховувати дії порушника, направлені на використання фізичних особливостей оптичного волокна.

\section{Висновок}


Запропонована модель загасання сигналу в оптико-волокнних лініях звя’зку, яка враховує загасання, спричинене як фізичними особливостями оптичного волокна так i навмисними діями на ОВ потенційного порушника, може бути застосована при проектуванні засобів захисту інформації в системах передачі інформації з використанням ВОЛЗ, а також для оцінки захищеності інформації. 


\section{Список літератури}

1.Скляров О.К.-Современные волоконно-оптические системы передачи, апаратура и елементы. Скляров О.К. - М.:Солон- Р, 2001. -240с.

2.Kaiser G/- Optical Fibre Communications. McGraw-Hill, 2nd Ed., 1991. Ch2-3.

3.Гроднев И.И. Волоконно-оптические линии связи/ Гроднев И.И. - М.: Радио и связь, 1990. -224с.

4.Гальярди Р.М. - Оптическая связь/ Гальярди Р.М., Капри Ш.И. - М.: Связь, 1978. -424c.

5.Гринфилд Д. - Оптические сети/ Гринфилд Д. - К.: ООО»Тид ДС», 2002 - 256c.

Речензент: д.т.н., проф. Корченко О.Г.

Надійшла 25.02.2010 p. 